The Canadian Mineralogist

Vol. 38, pp. 695-705 (2000)

\title{
ORIENTATION OF EXSOLUTION LAMELLAE AND RODS, AND OPTIMAL PHASE-BOUNDARIES IN ANTIPERTHITE FROM PELITIC GRANULITES, SRI LANKA
}

\author{
PETER RAASE $\$$ \\ Institut für Geowissenschaften der Universität Kiel, D-24098 Kiel, Germany
}

\begin{abstract}
The exsolution microtexture of antiperthite grains with bulk compositions $\mathrm{Or}_{17-21} \mathrm{An}_{33-26}$ from pelitic granulites from the Highland Complex of Sri Lanka were studied by optical methods. The most common K-feldspar rods are oblique to the $c$ axis by about $5^{\circ}$ and obviously nucleated at pre-existing albite-twin boundaries. Where no primary twin boundaries existed, exsolution lamellae of K-feldspar developed. This exsolution resulted in the formation of secondary albite-twin lamellae in the host plagioclase adjacent to the K-feldspar. A large range of orientations of exsolution lamellae has been measured on the universal stage and compared with low lattice-misfit boundaries calculated with the EPLAG program. A best fit is obtained using cell parameters for ordered plagioclase $\left(\mathrm{An}_{27-37}\right)$ and orthoclase. Nearly all poles to measured lamellae lie between (120) and (211) in the low-misfit belts defined by isolines showing $20 \%$ deviation from the lattice-misfit minimum when albite-twin-related cell parameters for the plagioclase host are included. Estimated unit-cell parameters for in situ conditions of exsolution yield insignificantly different optimal phase-boundaries. Results of the optical study and lattice-misfit considerations suggest that initially exsolved lamellae of K-feldspar, during very slow cooling under dry conditions, coarsened and rotated, and Al-Si ordering of the coexisting feldspar phases induced secondary albite-twin lamellae in the plagioclase host.
\end{abstract}

Keywords: antiperthite, feldspar, exsolution, orientation of exsolution lamellae, optimal phase- boundary, albite-twin lamellae, metapelites, Sri Lanka.

\section{SOMMAIRE}

La microtexture d'exsolution des grains d'antiperthite ayant une composition globale $\mathrm{Or}_{17-21} \mathrm{An}_{33-26}$ et provenant de granulites pélitiques du complexe de Highland, au Sri Lanka, a été étudiée par méthodes optiques. Dans la plupart des cas, le feldspath potassique de présente en tiges obliques à l'axe $c$ selon environ $5^{\circ}$; celles-ci ont évidemment pris germe dans les plans de macle (loi de l'albite) pré-existants. Là où il n'y avait pas de plans de macle, ce sont des lamelles d'exsolution de feldspath potassique qui se sont développées. L'exsolution a mené à la formation de macles (loi de l'albite) secondaires dans le plagioclase hôte voisin du feldspath potassique. L'orientation des lamelles d'exsolution varie largement, selon les mesures prises au moyen d'une platine universelle; ces orientations ont été comparées avec l'orientation des plans de décalage minimal entre réseaux au moyen du logiciel EPLAG. La meilleure concordance est celle qui est fondée sur les paramètres réticulaires d'un plagioclase ordonné $\left(\mathrm{An}_{27-37}\right)$ et de l'orthoclase. Presque tous les pôles mesurés des lamelles se situent entre (120) et (21̄i), dans la zone de décalage minimal tel que définie par les contours montrant $20 \%$ de déviation de cette valeur minimale dans le cas où les paramètres réticulaires du plagioclase hôte maclé selon la loi de l'albite sont utilisés. Les paramètres réticulaires ajustés pour refléter les conditions lors de l'exsolution mènent à des orientations optimales de l'interface entre phases presque identiques. Les résultats de l'étude optique et les considérations de la correspondance maximale des réseaux font penser que les lamelles exsolvées de feldspath potassique ont grossi et se sont tordues au cours du refroidissement très lent sous conditions anhydres; de plus, la mise en ordre $\mathrm{Al}-\mathrm{Si}$ des feldspaths coexistants a causé des macles secondaires dans le plagioclase hôte.

(Traduit par la Rédaction)

Mots-clés: antiperthite, feldspath, exsolution, orientation des lamelles d'exsolution, interface optimale entre phases, lamelles de macles d'albite, métapélites, Sri Lanka.

§E-mail address: pr@min.uni-kiel.de 


\section{INTRODUCTION}

Antiperthite consists of an intergrowth of rods, blebs, or lamellae of K-rich alkali feldspar in a plagioclase host. Antiperthite most commonly occurs in slowly cooled granulite-facies rocks (Eskola 1952, Sen 1959), anorthosites (Carstens 1967, Kay 1977), and pegmatites (Andersen 1928). Whereas very fine and regular intergrowths of two feldspars in syenitic rocks can only be explained by exsolution (Brown \& Parsons 1988, Smith \& Brown 1988), the intergrowth texture in antiperthite from granulites is commonly coarse and irregular, and may be explained either by replacement of plagioclase by alkali feldspar involving fluid transport along dislocations (Griffin 1969), or by coarsening of fine-scale intergrowths formed by exsolution. Since coarsening is largely enhanced by fluids (Parsons 1978), a coarsened exsolution-induced texture may not readily be distinguished from a replacement texture.

Various antiperthitic textures have been described, but only few systematic studies of the interface orientations between the K-rich phase and the plagioclase host have been carried out (Kay 1977, Propach \& Appelt 1994). Kay (1977) found a large range of orientations of the flattened surface of K-rich blebs in plagioclase and compared this range with the orientation of minimum interfacial energy for peristerite intergrowths calculated by Willaime \& Brown (1972).

Brown \& Parsons $(1984,1988)$ studied the microtexture, exsolution and coarsening mechanisms in ternary feldspars of syenites from the Klokken intrusion, in Greenland. Ab-rich and An-poor monoclinic alkali feldspars first exsolve ( $\overline{6} 01)$ lamellae, and then develop zigzag $(\overline{6} \overline{6} 1)$ lamellae owing to the transformation to a triclinic symmetry during slow cooling. In more An-rich alkali feldpars, the exsolved (601) lamellae do not change orientation, but develop corrugated interfaces during cooling. In contrast to monoclinic feldspars, triclinic plagioclase exsolves K-feldspar platelets that are oblique to $b^{*}$ by $5-10^{\circ}$. In K-rich plagioclase, these platelets enlarge during cooling, induce albite-twin lamellae in the adjacent plagioclase, develop corrugated interfaces, and rotate partly in a position parallel to $b^{*}$ and partly oblique thereto by $10-20^{\circ}$ (Brown \& Parsons 1988).

In the pelitic granulites from the Highland Complex of Sri Lanka, antiperthite porphyroclasts with a rather regular intergrowth-texture have been attributed to exsolution (Raase 1998). The bulk compositions of these antiperthite porphyroclasts indicate very high temperatures of metamorphism. The antiperthite contains $\mathrm{K}$-feldspar rods approximately parallel to $c$ and several sets of exsolution lamellae with various orientations. Further, primary and secondary albite-twin lamellae, formed respectively before and after exsolution, are distinguished. Similar textural features as found by Brown \& Parsons (1988) in their TEM study are shown here to be resolved by the optical microscope. Interface orien- tations of lamellae in the antiperthite are measured and compared with interface orientations for K-feldspar and plagioclase calculated by minimizing lattice-misfit according to Fleet (1982).

\section{AnTIPERThite TeXtures}

Two textural types of antiperthite are distinguished in the pelitic granulites of Sri Lanka: rod antiperthite and lamellar antiperthite. Rod antiperthite is the most common. The rods of K-feldspar are elongate approximately parallel to $c$. K-feldspar rods are relatively coarse (5-50 $\mu \mathrm{m}$, rarely up to $200 \mu \mathrm{m}$ thick) and occur in a plagioclase host with albite-twin lamellae. Lamellar antiperthite contains K-feldspar lamellae or laths $(<10$ $\mu \mathrm{m}$ thick) with variable orientations of the interface. Kfeldspar rods appear in some domains of lamellar antiperthite grains. In these grains, the rods have a minor thickness $(<10 \mu \mathrm{m})$ corresponding to that of the exsolution lamellae. Whereas the rods are aligned along twin boundaries of relatively coarse albite-twin lamellae $(5-20 \mu \mathrm{m})$, the exsolution lamellae are found in domains without visible twin lamellae or containing very fine albite-twin lamellae $(<3 \mu \mathrm{m})$ (Figs. 1a, b). The rods obviously nucleated at the interfaces of the coarse twin-lamellae, and thus formed later than these. Apart from rods and lamellae, antiperthite grains with a coarse and irregular exsolution-induced texture are surrounded by a K-feldspar rim (Fig. 1a), which probably results from migration of some K-feldspar component to the grain boundary.

\section{Shape and orientation of the K-feldspar rods}

The K-feldspar rods generally have an irregular shape in cross-sections perpendicular to [001]. Some rods show flattening approximately parallel to (100) or, more commonly, at an angle of $40-60^{\circ}$ to $(010)$, i.e., in between (110) and (120) (Figs. 1b, c). These flattened rods appear to be transitional in shape to the K-feldspar lamellae. Furthermore, some rods show corrugated or serrated interfaces (Fig. 1b) similar to those shown by Brown \& Parsons (1988) in TEM studies of the cryptoantiperthitic intermediate zone of zoned ternary feldspars from the Klokken intrusion.

In sections perpendicular to [100], it can be seen that the rods deviate from the (010) twin plane by about 3$8^{\circ}$ and lie in the acute angle between (010) and (001) (Fig. 1d). Universal-stage measurements give an angle in the range of $64-69^{\circ}$ to [100] and a mean value of $6^{\circ}$ to [001] (Fig. 2).

\section{Orientation of the K-feldspar lamellae}

Most K-feldspar lamellae in the antiperthite grains can be seen in sections perpendicular to [001], where the rods also are observed. However, they do not show a sharp outline in thin section, indicating that their in- 

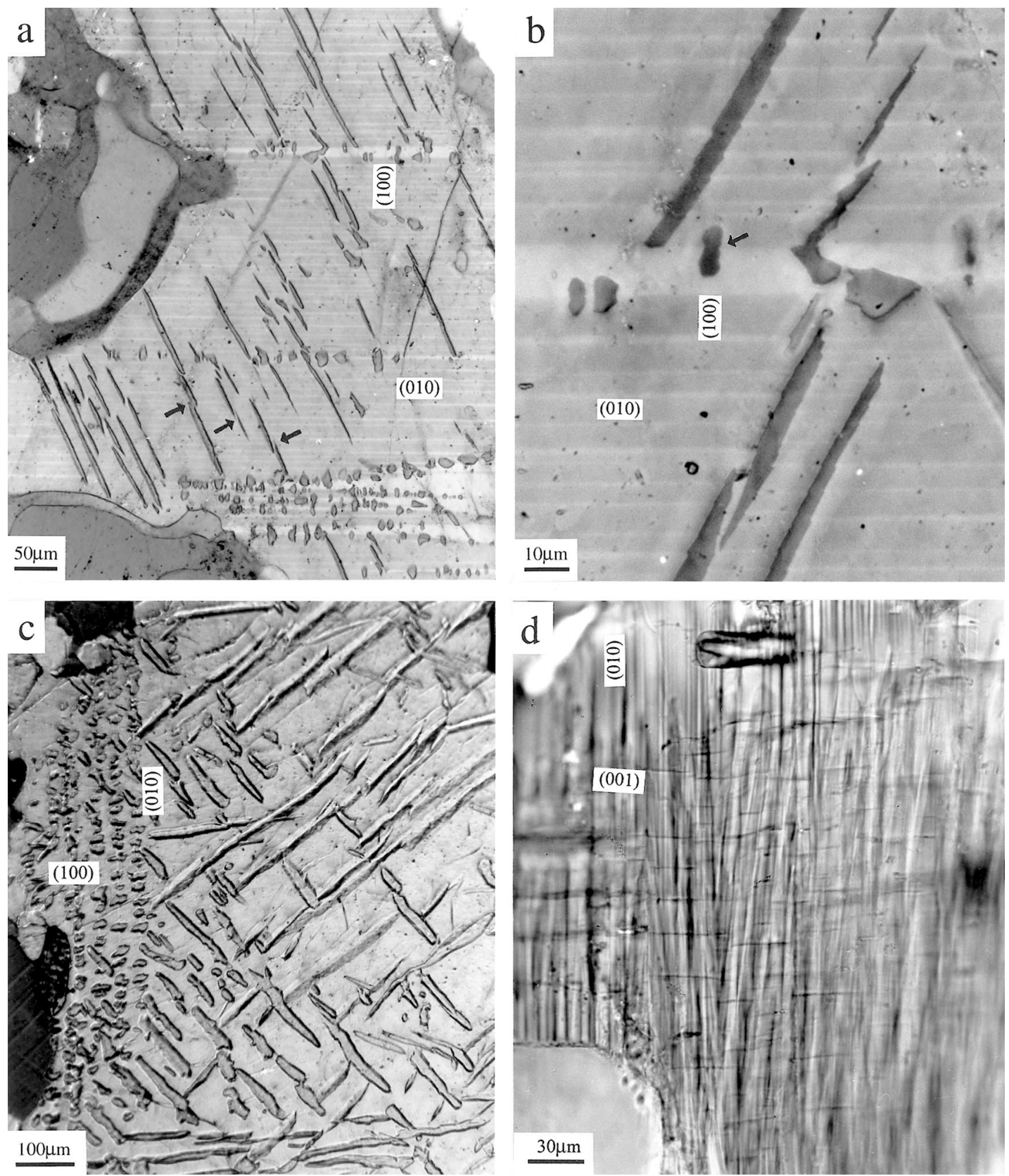

FIG. 1. Photomicrographs showing textures of antiperthite in pelitic granulites from Sri Lanka. (a) K-feldspar lamellae and cross-sections of rods, the latter aligned along coarser albite-twin lamellae (light). Note en échelon texture of some K-feldspar lamellae (arrows), and K-feldspar rim at the grain boundary. Sample 369, section perpendicular to [001], crossed polars. (b) Detail from (a) showing serrated interfaces at the contact with the fine secondary twin-lamellae and cross-sections of rods flattened parallel to (100) with serrated interface (arrow). (c) Several sets of K-feldspar lamellae with different interface orientations (partly curved). Left-hand side: cross-sections of rods aligned along albite-twin lamellae (not visible). Sample 238, section perpendicular to [001], crossed polars. (d) Longitudinal section of K-feldspar rods in albite-twinned plagioclase showing a deviation of the rod orientation against the $(010)$ plane of about $7^{\circ}$. Note the different orientation of rods and traces of (001) cleavage in different twin individuals. Sample 461, section perpendicular to [100], crossed polars. 
terface generally does not lie in the zone [001]. In most antiperthite grains, there are several sets of exsolution lamellae, with largely different orientations of the interface (Fig. 1c). In some grains, there are several sets of lamellae at small angles $\left(<10^{\circ}\right)$ one from another. Further, there are also curved interfaces (Fig. 1c). The curvature cannot be due to deformation of the grains, since, in this case, neighboring interfaces should bend in the same direction. In some places, the orientation of the interface of the finer exsolution-lamellae is slightly different from that of neighboring coarser lamellae. Some coarser lamellae appear to be split into finer lamellae arranged in an en échelon texture (Fig. 1a). In places, where the exsolution lamellae are crossed by fine albite-twin lamellae, a serrate interface is observed (Fig. 1b) and results from a change of orientation of the interface that depends on the twin position of the plagioclase host. The observation that the twin lamellae and serrations on opposite sides of the exsolution lamellae differ in spacing (Fig. 1b) suggests that the twin lamellae formed later than the exsolution lamellae, and subsequently the orientation of the interface adapted to the twin positions of the plagioclase host.

The orientation of the K-feldspar lamellae in the antiperthite has been measured on a universal stage relative to the crystallographic axes, which in turn are determined from the position of the (010) twin axis, the (001) cleavage plane and the indicatrix axes. Since the few data for the optical orientation of exsolution lamellae in antiperthite reported in the literature are determined in oriented sections or cleavage flakes (Smith 1974), the universal-stage procedure applicable for normal thin sections is described as follows: (1) The pole to the interface of the exsolution lamellae is measured by orienting the thin section so that the interface is ver-

TABLE 1. COMPOSITION OF FELDSPARS IN METAPELITES FROM SRI LANKA

\begin{tabular}{|c|c|c|c|c|c|c|}
\hline \multirow[t]{2}{*}{ No. } & & \multicolumn{2}{|c|}{$\begin{array}{l}\text { Plagioclase host } \\
\text { of antiperthite: } \\
\text { distance from } \\
\text { K-feldspar lamellae }\end{array}$} & \multirow{2}{*}{$\begin{array}{c}\text { K-feldspar } \\
\text { lamellae } \\
\text { mole } \\
\%\end{array}$} & \multirow{2}{*}{$\begin{array}{c}\text { Bulk } \\
\text { antiperthite } \\
\text { mole } \\
\%\end{array}$} & \multirow{2}{*}{$\begin{array}{c}\text { Bulk } \\
\text { perthite } \\
\text { mole } \\
\%\end{array}$} \\
\hline & & $25 \mu \mathrm{m}$ & $5 \mu \mathrm{m}$ & & & \\
\hline \multirow[t]{3}{*}{238} & An & 39 & 43 & 0.4 & 33 & 1.1 \\
\hline & $\mathrm{Ab}$ & 60 & 56 & 7.6 & 50 & 11.2 \\
\hline & $\mathrm{Or}$ & 1 & 1 & 92.0 & 17 & 87.7 \\
\hline \multirow[t]{3}{*}{369} & An & 28 & 34 & 0.5 & 26 & 1.4 \\
\hline & $\mathrm{Ab}$ & 71 & 65 & 8.3 & 53 & 16.4 \\
\hline & Or & 1 & 1 & 91.2 & 21 & 82.2 \\
\hline \multirow[t]{3}{*}{461} & An & & 32 & 0.3 & 26 & 2.4 \\
\hline & $\mathrm{Ab}$ & & 65 & 9.9 & 54 & 16.3 \\
\hline & $\mathrm{Or}$ & & 1 & 89.8 & 20 & 81.3 \\
\hline
\end{tabular}

The compositions of plagioclase host and $\mathrm{K}$-feldspar lamellae in antiperthite were established by electron-microprobe point analyses with a slightly defocussed beam. The bulk compositions of the antiperthite and perthite are integrated by electron-microprobe scanning analyses or by image analysis ofback-scattered electron images (Raase 1998). tical and appears as thin trace under the microscope. The pole to the lamellae is then horizontal. (2) The orientation of the rods is measured by tilting the thin section to a position where all interfaces appear as sharp traces. The longitudinal axis of the rods is then vertical. (3) The crystallographic $a$ axis or the zone axis [100] is measured as the intersection between the (010) twin plane and the (001) cleavage plane. (4) The position of the $c$ axis is then obtained by counting $116^{\circ}(=\beta)$ on the Wulff net from the [100] pole on the trace of the (010) plane in the direction toward the pole to (001). The positive (001) pole lies about $4^{\circ}$ from the trace of the $(010)$ plane on the same side as the pole to $(010)$. Where the [100] zone axis could not be measured because of large tilts, the position of the $c$ axis was estimated from the position of the K-feldspar rods (see above). (5) The $b$ axis lies in the (001) plane and at about $94^{\circ}(=\alpha)$ to $c$ in the plane defined by $c$ and the pole to (010). (6) The angles between the poles to the interfaces of the exsolution lamellae and the crystallographic axes are determined on the Wulff net.

The error of the universal-stage measurements is generally less than $5^{\circ}$. Depending on the straightness of the lamellar boundaries, the deformation of the grains, the angle of tilt of the lamellae, the (010) twin plane and the (001) cleavage plane, however, a deviation of more than $5^{\circ}$ seems probable in some cases.

For three samples of antiperthite in pelitic granulites from Sri Lanka, the poles to the interfaces of K-feldspar exsolution lamellae and the orientation of the long axis of the rods are plotted on a Wulff net (Fig. 2). The compositions of the host plagioclase, and of the K-feldspar lamellae or rods, and the bulk composition of the antiperthite grains and of coexisting perthite grains, are given in Table 1. Although a large range of lamellae orientations is shown in Figure 2, most poles to lamellae appear to lie on a small-circle girdle at an angle of $25-50^{\circ}$ inclined with respect to $(100)$. The poles to the lamellae concentrate in between the $h \mathrm{kl}$ poles for (110), (101) and (110), between (120) and ( $\overline{3} 21)$, and between $(\overline{2} \overline{1} 1)$ and $(\overline{1} \overline{2} 0)$ (Fig. 2), but there is a gap near the $-a$ axis and near the poles to the exsolution lamellae in alkali feldspar that are near $(\overline{6} 01)$ and $(\overline{8} 01)$ (Bøggild 1924). The occurrence of continuous ranges of intermediate orientations suggests that the lamellae are oriented parallel to planes with irrational indices. There is no obvious dependence of lamellae orientation upon the An content of the host plagioclase, which is significantly higher in sample $238\left(\mathrm{An}_{43}, 5 \mu \mathrm{m}\right.$ from the contact) than in samples 369 and $461\left(\mathrm{An}_{32-34}\right.$, see Table 1). The plagioclase host of samples 238 and 369 exhibits a distinct zonation in An over a distance of about $20 \mu \mathrm{m}$ from the contact with the K-feldspar lamellae (Table 1). Although the coarse lamellae in the antiperthite are now most probably incoherent, they might have first exsolved coherently on irrational planes.

Definite orientations of interfaces between K-feldspar lamellae and plagioclase host with irrational $h k l$ 
indices are expected from the lattice-misfit theory (Bollmann \& Nissen 1968, Robinson et al. 1971, 1977, Fleet 1982) and the coherent elastic strain model (Willaime \& Brown 1974). The orientation of the optimal phase-boundary is predicted by minimizing the area-misfit between normalized equivalent $h k l$ planes in two related three-dimensional lattices (Fleet 1982). The lattice-misfit was calculated with the computer program EPLAG by Fleet (1982) for several sets of well-studied samples of plagioclase and alkali feldspar, the compositions of which are comparable to those of the unmixed phases of the antiperthite from Sri Lanka. EPLAG calculates the lattice-misfit for grid points at an interval of $5^{\circ}$, and each grid point is the location of a stereographic pole to an interface plane.

Isolines for $20 \%$ deviation from the misfit minimum are calculated with the cell dimensions of natural oligoclase (No. 1 in Table 2) and orthoclase (No. 5 in Table 2) and are projected onto the $a^{*}-c^{*}$ plane together with the measured stereographic poles to the lamellae interfaces in the antiperthite samples from Sri Lanka (Fig. 3). A second set of isolines is calculated with unit-cell parameters of the plagioclase host modified by $\alpha^{\prime}=180^{\circ}$ $-\alpha, \gamma^{\prime}=180^{\circ}-\gamma$ (Fleet 1982), in order to account for a nucleation of the exsolution lamellae on different sides of the albite twin plane (010). Most of the poles to the lamellae interfaces lie well within $20 \%$ deviation from the misfit minima calculated with the two sets of cell parameters (Fig. 3). Further, most poles are in the lowmisfit belt between (120) and (21) , between (120) and $(\overline{2} 1 \overline{1})$, and in the respective ranges for the albite twin. Thus, the large range of observed orientations of lamellae reduce to twin-related low-misfit bands that extend over $40-50^{\circ}$ in the Wulff net. All measured poles to exsolution lamellae represent sets of approximately parallel lamellae, although individual lamellae in each set may be slightly curved, and neighboring lamellae may have slightly different orientations.

In order to evaluate the range of variation of orientations within one set of lamellae, detailed measurements of individual lamellae within one grain (sample 461) are plotted in Figure 4. This set of poles to lamellae yields a band extending over $15^{\circ}$ parallel to the isolines within $10 \%$ deviation from the lattice-misfit minimum. Similar misfit minima were calculated for feldspar pairs with cell parameters of more An-rich plagioclase $\left(\mathrm{An}_{37}\right.$,

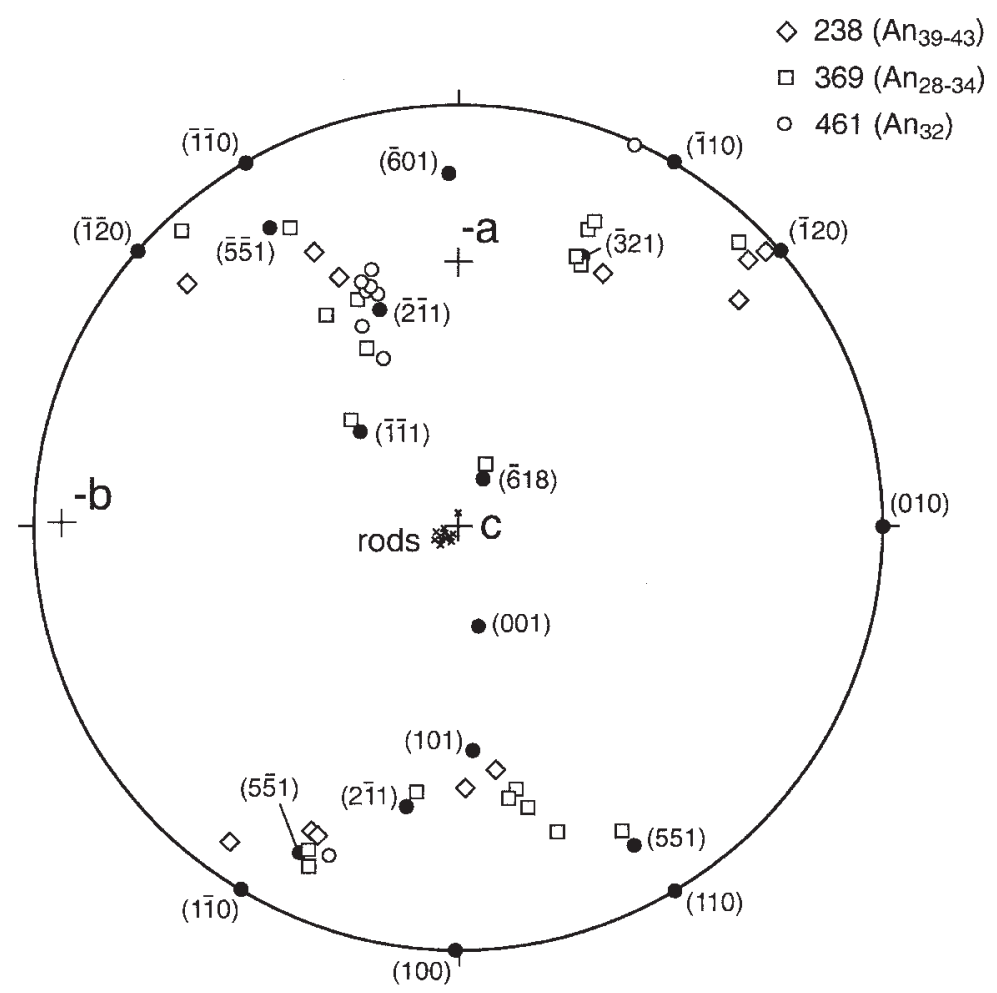

FIG. 2. Plot of the position of K-feldspar rods and the poles to K-feldspar lamellae for three antiperthite samples (Table 1) projected onto the plane perpendicular to [001] (Wulff net, upper hemisphere). The poles to some $h k l$ planes of oligoclase (Table 2) are given for comparison (black dots). 
TABLE 2. CELL PARAMETERS USED IN THE LATTICE-MISFIT CALCULATIONS

\begin{tabular}{|c|c|c|c|c|c|c|c|c|c|c|c|}
\hline \multirow{2}{*}{\multicolumn{2}{|c|}{ Feldspar }} & \multicolumn{3}{|c|}{ Composition } & \multicolumn{6}{|c|}{ Cell parameters } & \multirow[t]{2}{*}{ Reference } \\
\hline & & An & Or & $\mathrm{Ab}$ & $a(\AA)$ & $b(\AA)$ & $c(\AA)$ & $\alpha\left(^{\circ}\right)$ & $\beta\left(^{\circ}\right)$ & $\gamma\left({ }^{\circ}\right)$ & \\
\hline 1 & Oligoclase & 26.8 & 3.4 & 69.5 & 8.171 & 12.846 & 7.129 & 93.75 & 116.44 & 89.25 & $97490[1],[2]$ \\
\hline 2 & Andesine $\left(300^{\circ} \mathrm{C}\right)$ & 36.4 & 0.7 & 62.9 & 8.170 & 12.855 & 7.117 & 93.40 & 116.29 & 89.63 & F50 [3] \\
\hline 3 & $\begin{array}{l}\text { same as } 2 \text {, adjusted } \\
\text { for }+2 \% \text { Or }\end{array}$ & 36.4 & 2.7 & 60.9 & 8.180 & 12.861 & 7.120 & 93.32 & 116.26 & 89.63 & Footnote 1 \\
\hline 4 & $\begin{array}{l}\text { same as } 3 \text {, adjusted } \\
\text { for } \mathrm{Al} / \mathrm{Si} \text { disorder }\end{array}$ & 36.4 & 2.7 & 60.9 & 8.172 & 12.873 & 7.108 & 93.18 & 116.18 & 89.97 & Footnote 2 \\
\hline 5 & Orthoclase & 0.7 & 90.5 & 8.4 & 8.562 & 12.996 & 7.193 & 90 & 116.01 & 90 & Spencer C [4], [5] \\
\hline 6 & Orthoclase & & 85.9 & & 8.561 & 12.995 & 7.194 & 90 & 115.99 & 90 & P50-56F [6] \\
\hline 7 & Low sanidine & 0.0 & 85.4 & 14.6 & 8.539 & 13.015 & 7.179 & 90 & 115.99 & 90 & $7002[7]$ \\
\hline
\end{tabular}

Precision: $\pm 0.002 \AA$ and $\pm 0.02^{\circ}$ except for predicted unit-cell parameters 3 and 4

Footnotes: (1) Unit-cell parameters adjusted for $\mathrm{KNa}$ exchange according to data from Hovis (1986). (2) Unit-cell parameters adjusted for $\mathrm{A} 1 / \mathrm{Si}$ disorder according to the data of Bambauer et al. (1967) and Kroll (1967).

References: [1] Smith (1956), [2] Ribbe \& Smith (1966), [3] Grundy \& Brown (1974), [4] Cole et al. (1949), [5] Smith \& Ribbe (1966), [6] Wright \& Stewart (1968), [7] Phillips \& Ribbe (1973).

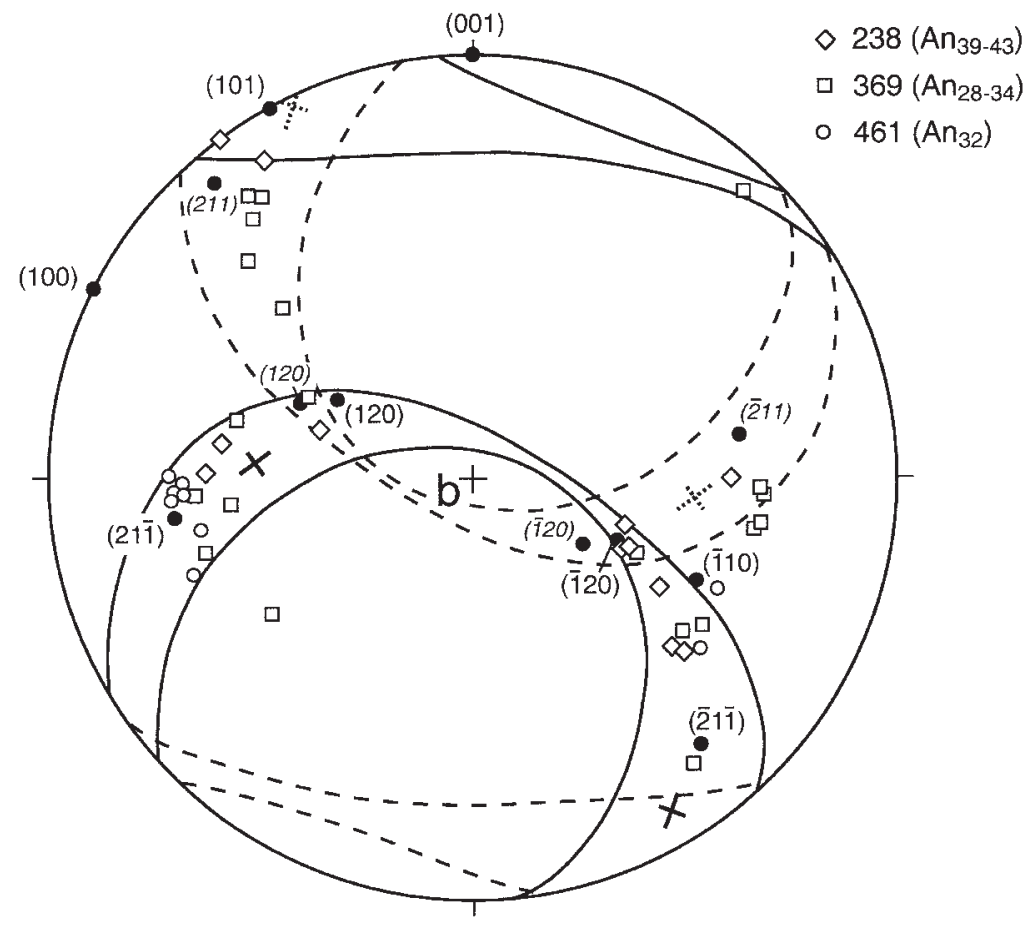

FIG. 3. Plot of the poles to K-feldspar lamellae for three antiperthite samples (Table 1), lattice-misfit minima (oblique crosses), and isolines for $20 \%$ deviation from the latticemisfit minima, calculated according to Fleet (1982) for the pair oligoclase-orthoclase (solid lines, No. 1 and 5 in Table 2), projected onto the plane perpendicular to $b$ (Wulff net, upper hemisphere). Broken lines are calculated with albite-twin-related cell parameters, and positions with italic $h k l$ indices are related to the albite twin of the host plagioclase. 


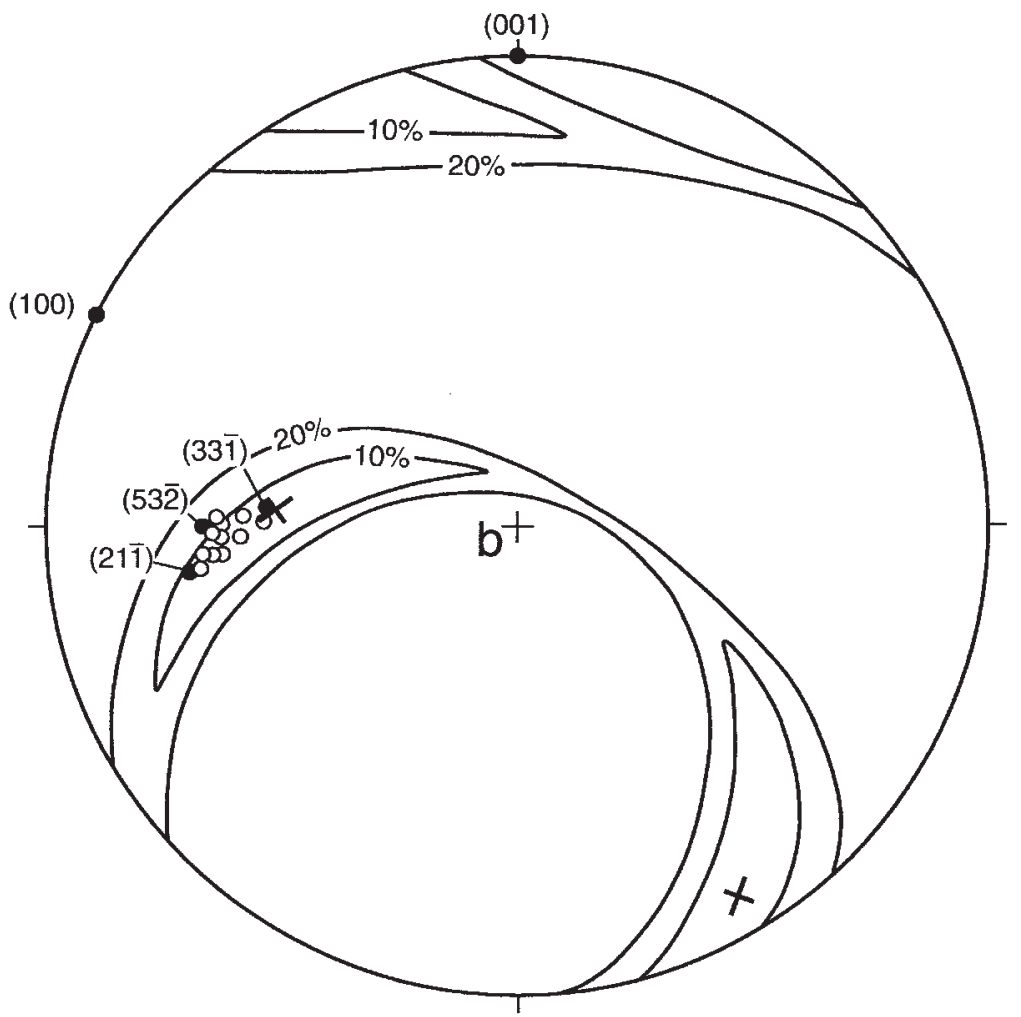

FIG. 4. Plot of the poles to individual K-feldspar-plagioclase interfaces of one set of Kfeldspar lamellae within one antiperthite grain (Sample 461), compared with isolines for $10 \%$ and $20 \%$ deviation from the lattice-misfit minimum as in Figure 3.

Bambauer et al. 1967), low sanidine (Or 85 , Phillips \& Ribbe 1973), and ion-exchanged orthoclase (Or 75 , Wright \& Stewart 1968). Distinctly different misfitminima, which are at variance with the measured orientations of the interface in the antiperthite samples, were obtained with unit-cell parameters of synthetic high sanidine $\left(\mathrm{Or}_{64}, \mathrm{Or}_{74}\right.$, Orville 1967) and intermediate microcline ( $\mathrm{Or}_{87}$, Bailey \& Taylor 1955$)$.

Since the interface orientation depends on the cell dimensions of the two feldspar lattices at the time of exsolution or at the time when the exsolution and reequilibration process stopped, the misfit-minima calculations should be done with cell parameters measured at the pressures and temperatures of metamorphism of the rocks and with the composition and structural state of the feldspars during the exsolution. The conditions for the closure of the processes of exsolution and re-orientation of the interface between the coarse $\mathrm{K}$-feldspar lamellae and the plagioclase host are estimated at $600^{\circ} \mathrm{C}$ and 4 kbar under dry conditions and slow cooling (Raase 1998). Since insufficient data on high-pressure and hightemperature cell parameters are available, only a rough estimate of the cell parameters of the feldspars at these conditions can be given.

The effect of increasing temperatures on the cell parameters of Ab-rich plagioclase is similar to that of substituting $\mathrm{K}$ for $\mathrm{Na}$ and opposite to that of increasing pressure (Brown et al. 1984). For oligoclase and andesine, the unit-cell parameters $a$ and, to a lesser extent, $b$ increase by heating, whereas the cell angles $\alpha$ and $\gamma$ decrease (Grundy \& Brown 1974). The magnitude of the increase in $a$ and $b$ of albite expected to result from an increase of temperature to $600^{\circ} \mathrm{C}$ is about double the magnitude of the decrease in these cell parameters due to an increase of pressure to $4 \mathrm{kbar}$ (Hazen \& Prewitt 1977). Assuming a similar relation for the plagioclase, cell parameters measured at $300^{\circ} \mathrm{C}$ and 1 bar may be taken for the lattice-misfit calculations. For plagioclase with $36 \mathrm{~mol} \%$ An and $0.7 \mathrm{~mol} \%$ Or, the cell parameters at $300^{\circ} \mathrm{C}$ have been reported by Grundy \& Brown (1974). At $600^{\circ} \mathrm{C}$ and $4 \mathrm{kbar}$, the plagioclase $\left(\mathrm{An}_{36}\right)$ coexisting with $\mathrm{K}$-feldspar should have contained $2.7 \mathrm{~mol} \%$ Or, calculated with the two-feldspar thermometer of Fuhrman \& Lindsley (1988). Therefore, the cell 
parameters for plagioclase $\mathrm{An}_{36} \mathrm{Or}_{0.7}$ at $300^{\circ} \mathrm{C}$ given by Grundy \& Brown (1974) should be corrected for +2 mol\% Or. This has been done by interpolation from the cell parameters for the microcline - low albite $\mathrm{K}-\mathrm{Na}$ exchange series given by Hovis (1986). Further, since the Al-Si distribution of the plagioclase might have been significantly disordered during exsolution at a temperature of $600^{\circ} \mathrm{C}$ and under dry conditions, the cell parameters under consideration are again modified by amounts corresponding to the differences between the respective cell parameters of low and high plagioclase (Bambauer et al. 1967, Kroll 1967). The inferred cell parameters used in the lattice-misfit calculations are given in Table 2.

Alkali feldspar coexisting with plagioclase $\left(\mathrm{An}_{36}\right.$ $\mathrm{Or}_{2.7}$ ) during exsolution at $600^{\circ} \mathrm{C}$ and $4 \mathrm{kbar}$ should contain $14 \mathrm{~mol} \% \mathrm{Ab}$ according to the thermometer model of Fuhrman \& Lindsley (1988). The lattice-misfit calculations were done with the cell parameters of orthoclase and low sanidine (No. 6 and 7 in Table 2), measured at room temperature and pressure. Increasing temperature affects the cell parameters of K-rich alkali feldspars to a much lesser degree than those of albite and plagioclase, and increasing pressure results in an opposite change (Brown et al. 1984). Thus, both effects may approximately cancel each other.

Isolines for $20 \%$ deviation from the lattice-misfit minima were calculated for two pairs of feldspars with cell parameters and compositions estimated for $600^{\circ} \mathrm{C}$ and 4 kbar, as outlined above. In Figure 5, these isolines are shown for ordered andesine $\left(\mathrm{An}_{36} \mathrm{Or}_{2.7}\right)$ and orthoclase (Table 2, Nos. 3 and 6, respectively), and for disordered andesine and low sanidine (Table 2, Nos. 4 and 7 , respectively) together with the stereographic poles to the lamella interfaces in the antiperthite grains from Sri Lanka. Compared with Figure 3, no large shift of isolines is observed, and most of the measured poles to lamella interfaces again have less than $20 \%$ deviation from the lattice-misfit minima. However, the isolines for ordered andesine and orthoclase fit significantly better to the measured poles than the isolines for disordered andesine and low sanidine.

\section{Discussion And Conclusions}

The orientation of K-feldspar lamellae near the lattice-misfit minima calculated for the interface between orthoclase and oligoclase-andesine is consistent with a formation of the antiperthite microtexture by exsolution and coarsening. During very slow cooling after highgrade granulite-facies metamorphism, a monoclinic Krich feldspar exsolved in a triclinic plagioclase host. The spread of lamella orientations is in part due to the breadth of the low-misfit belts and in part to the reorientation of the lamellae interfaces during cooling and, at the same time, the changing composition and structural state of the K-feldspar lamellae and the plagioclase host.
The observation of K-feldspar rods at interfaces of coarse albite-twin lamellae and the observation of exsolution lamellae in domains without these primary albite-twin lamellae can be interpreted to reflect heterogeneous nucleation of the rods and homogeneous nucleation of the exsolution lamellae. The elongation of the rods approximately parallel to the $c$ axis of the host feldspar probably is determined primarily by the direction of preferential growth, which, in turn, may be determined by line dislocations or other defects in the crystal structure. However, the serrated surface of the flattened rods transitional to lamellae appear to approach optimal phase-boundaries. The orientation of the serrated rodhost interfaces roughly in the zone [001] (Fig. 1b) conforms with the orientation of K-feldspar lamellae and with the calculated lattice-misfit minima. The formation of fine secondary albite-twin lamellae and serrated interfaces of K-feldspar lamellae (Fig. 1b) could be induced by strain at a monoclinic-triclinic interface. Three situations are conceivable:

(1) The secondary twin lamellae develop after exsolution owing to strain induced by inversion of an originally monoclinic ternary feldspar into a triclinic plagioclase. This seems improbable, since (a) ( 601$)$ lamellae, which typically exsolve in An-containing monoclinic alkali feldspars (Brown \& Parsons 1988) are missing, and (b) older albite-twin lamellae indicate a triclinic state prior to all exsolution.

(2) On the basis of a study of the exsolution microtextures in ternary feldspars from the Klokken syenite intrusion, Brown \& Parsons (1988) suggested that Kfeldspar lenses, which develop in a triclinic plagioclase host, are first constrained to triclinic symmetry and, during coarsening, relax to monoclinic symmetry whereby fine secondary albite-twin lamellae are induced. At the contact of the twin lamellae with the sanidine lenses, a corrugated interface develops, and the average interface rotates toward $b^{*}$ (Brown \& Parsons 1988, Figs. 7c, 8c). Some K-feldspar rods that nucleated at albite-twin boundaries in the antiperthite grains from Sri Lanka appear elongate approximately parallel to $b^{*}$ or flattened in the plane $b^{*}-c$, and the interface may show serrations. These flattened and serrated rods may have developed with corrugated interfaces from the sanidine lenses by coarsening owing to very slow cooling of the granulite-facies rocks. However, most exsolution lamellae in the antiperthite grains from Sri Lanka and some low sanidine lamellae in the feldspars from the Klokken syenite are oblique to $b^{*}$, and the secondary albite-twin lamellae related to these exsolution lamellae must have developed by another mechanism.

(3) During isobaric cooling in the lower crust of Sri Lanka (Raase \& Schenk 1994), sanidine exsolution lamellae developed in the ternary feldspars of the pelitic granulites and equilibrated with the plagioclase host, acquiring a low-strain optimal phase-boundary. During cooling to lower temperatures, the lattice of the triclinic plagioclase host became more oblique, i.e., the lattice 


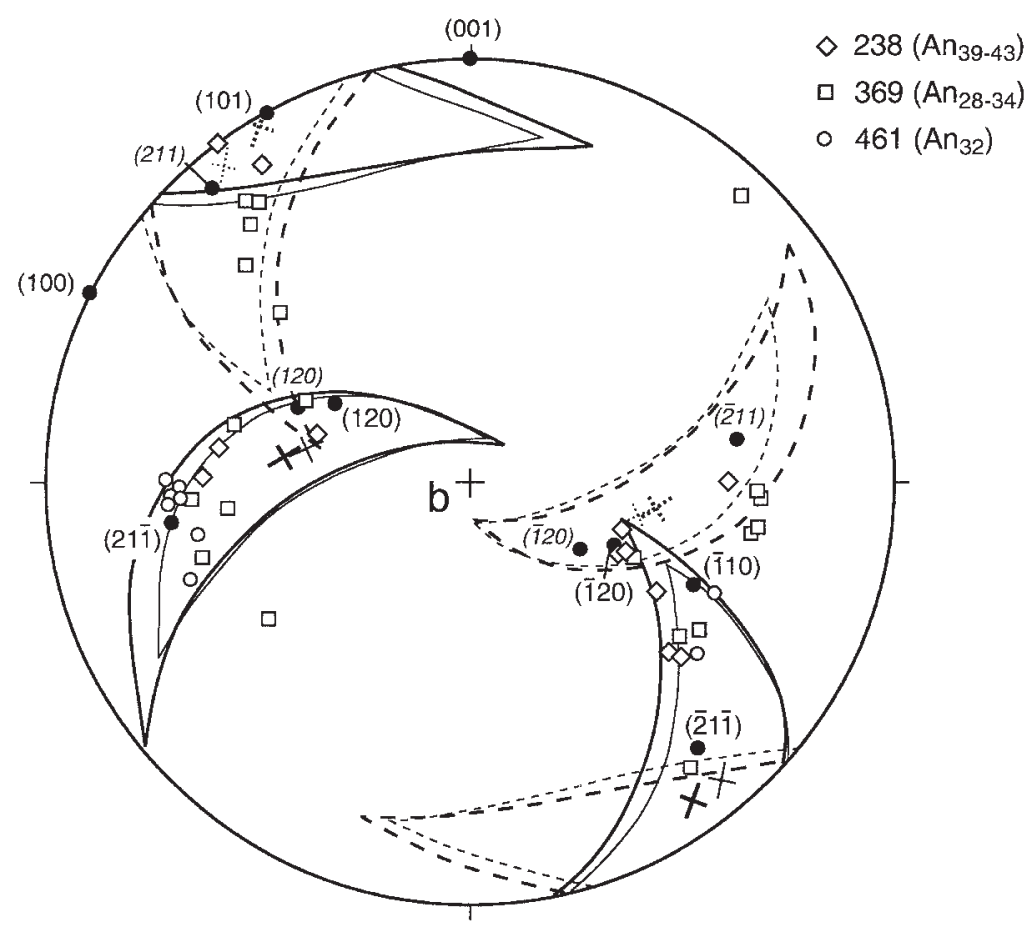

FIG. 5. Plot of the poles to K-feldspar lamellae as in Figure 3, lattice-misfit minima (oblique crosses), and isolines for $20 \%$ deviation from the lattice-misfit minima for two feldspar pairs with cell parameters and compositions estimated for $600^{\circ} \mathrm{C}$ and $4 \mathrm{kbar}$ (see text). Heavy solid lines: ordered andesine-orthoclase (Nos. 3 and 6 in Table 2), heavy broken lines: same pair with albite-twin-related cell parameters of ordered andesine; light solid lines: disordered andesine-low sanidine (Nos. 4 and 7 in Table 2), light broken lines: same pair with albite-twin-related cell parameters of disordered andesine.

angle $\alpha$ decreased, while the alkali feldspar lamellae were still monoclinic. As long as the exsolution lamellae were at least semicoherent with the plagioclase host, the increasing strain-energy associated with the interface may be reduced by rotation of the interface. On the other hand, strain energy may be reduced by lamellar twinning of the plagioclase host according to the albite law, since the albite-twin-related lattices of the plagioclase at the conditions of late-stage metamorphism differ in the lattice angle $\alpha$, which is the main lattice angle responsible for the change of obliquity. Through lamellar twinning of the plagioclase host, the serrated average plagioclase-K-feldspar interface does not rotate, although, inside the twin lamellae, the interface must rotate with increasing obliquity of the plagioclase host, and the amount of rotation is related to the width and spacing of the twin lamellae. Inside the twin lamellae, the plagioclase-K-feldspar interface may still remain coherent, but near the contact of the twin lamellae with the monoclinic K-feldspar, the interface will probably become incoherent.
During very slow cooling, coarsening of the exsolution lamellae and the secondary twin lamellae could make the serrated interfaces optically visible, and further rotation of the interfaces will occur. Older exsolution lamellae with serrated interfaces may also continue to grow with different orientation under changed metamorphic conditions, resulting in curved or kinked interfaces. Further coarsening and reorientation of the interfaces under decreasing P-T conditions may also explain the development of slightly different orientations of successive generations of lamellae, especially the observed en échelon pattern in some grains of antiperthite.

Lamellar microtextures in antiperthite appear to be preserved only under favorable circumstances, i.e., under essentially dry conditions during slow isobaric cooling after granulite-facies metamorphism. Nethertheless, antiperthite grains with heterogeneously exsolved Kfeldspar rods are much more common, even in the Sri Lankan granulites. Clearly, lamellar antiperthite only forms where twin lamellae or other heterogeneities in 
the feldspar grains were absent or sparse as the exsolution process began during cooling. Further, diffusion must have been so slow that the heterogeneously exsolved rods could not grow over the whole grain before the activity barrier for homogeneous exsolution was overcome.

\section{ACKNOWLEDGEMENTS}

This study emerged from a priority research project on the lower continental crust supported by the Deutsche Forschungsgemeinschaft. I thank G. Bissert and G. Braun for their assistance in the computer calculations. I am very grateful to $\mathrm{H}$. Kroll for encouraging comments, and to J.C. Schumacher, R.F. Martin, and E. Smelik for constructive reviews.

\section{REFERENCES}

ANDERSEN, O. (1928): The genesis of some types of feldspar from granite pegmatites. Norsk Geol. Tiddskr. 10, 116-207.

BAILEY, S.W. \& TAYLOR, W.H. (1955): The structure of a triclinic potassium feldspar. Acta Crystallogr. 8, 621-632.

Bambauer, H.U., Eberhard, E. \& Viswanathan, K. (1967): The lattice constants and related parameters of "plagioclases (low)". Part IV of laboratory investigations on plagioclases. Schweiz. Mineral. Petrogr. Mitt. 47, 351-364.

BøGGILD, O.B. (1924): On the labradorization of the feldspars. K. danske vidensk. selsk. Mat.-Fys. Meddel. 6, 1-79.

BollmanN, W. \& NisSEN, H.U. (1968): A study of optimal phase boundaries: the case of exsolved alkali feldspars. Acta Crystallogr. A24, 546-557.

Brown, W.L., Openshaw, R.E., McMillan, P.F. \& HenDERSON, C.M.B. (1984): A review of the expansion behavior of alkali feldspars: coupled variations in cell parameters and possible phase transitions. Am. Mineral. 69, 1058-1071.

\& PARSONS, I. (1984): Exsolution and coarsening mechanisms and kinetics in an ordered cryptoperthite series. Contrib. Mineral. Petrol. 86, 3-18.

$\&$ (1988): Zoned ternary feldspars in the Klokken intrusion: exsolution microtextures and mechanisms. Contrib. Mineral. Petrol. 98, 444-454.

Carstens, H. (1967): Exsolution in ternary feldspars. I. On the formation of antiperthites. Contrib. Mineral. Petrol. 14, 27 35.

Cole, W.F., Sørum, H. \& Kennard, O. (1949): The crystal structures of orthoclase and sanidinized orthoclase. Acta Crystallogr. 2, 280-287.

Eskola, P. (1952): The granulites of Lapland. Am. J. Sci., Bowen Vol., 133-171.
FLeET, M.E. (1982): Orientation of phase and domain boundaries in crystalline solids. Am. Mineral. 67, 926-936.

FuHRMAn, M.L. \& LindSLEy, D.H. (1988): Ternary-feldspar modeling and thermometry. Am. Mineral. 73, 201-215.

GRIFFIN, W.L. (1969): Replacement antiperthites in gneisses in the Babbitt-Embarrass area, Minnesota, U.S.A. Lithos 2, 171-186.

GRUNDY, H.D. \& BRown, W.L. (1974): A high-temperature Xray study of low and high plagioclase feldspars. In The Feldspars (W.S. MacKenzie \& W.L. Brown, eds.). Manchester University Press, Manchester, U.K. (162-173).

Hazen, R.M. \& PrewitT, C.T. (1977): Linear compressibilities of low albite: high-pressure structural implications. Am. Mineral. 62, 554-558.

Hovis, G.L. (1986): Behavior of alkali feldspars: crystallographic properties and characterization of composition and Al-Si distribution. Am. Mineral. 71, 869-890.

KAY, S.M. (1977): The origin of antiperthites in anorthosites. Am. Mineral. 62, 905-912.

KROLL, H. (1967): Untersuchungen an synthetischen HochTemperatur-Plagioklasen. Diplomarbeit, Westfälische Wilhelms-Universität Münster, Münster, Germany.

ORVILLE, P.M. (1967): Unit-cell parameters of the microcline - low albite and sanidine - high albite solid solution series. Am. Mineral. 52, 55-86.

PARsons, I. (1978): Feldspars and fluids in cooling plutons. Mineral. Mag. 42, 1-17.

Phillips, M.W. \& RibBE, P.H. (1973): The structures of monoclinic potassium-rich feldspars. Am. Mineral. 58, 263-270.

Propach, G. \& Appelt, M. (1994): Antiperthite in a mafic xenolith from a volcanic breccia in northern Bavaria. Eur. J. Mineral. 6, 537-545.

RAASE, P. (1998): Feldspar thermometry: a valuable tool for deciphering the thermal history of granulite-facies rocks, as illustrated with metapelites from Sri Lanka. Can. Mineral. 36, 67-86.

\& SCHENK, V. (1994): Petrology of granulite-facies metapelites of the Highland Complex, Sri Lanka: implications for the metamorphic zonation and the $\mathrm{P}-\mathrm{T}$ path. Precamb. Res. 66, 265-294.

Ribbe, P.H. \& Smith, J.V. (1966): X-ray emission microanalysis of rock-forming minerals. IV. Plagioclase feldspars. J. Geol. 74, 217-233.

Robinson, P., JafFe, H.W., Ross, M. \& Klein, C., JR. (1971): Orientation of exsolution lamellae in clinopyroxenes and clinoamphiboles: consideration of optimal phase boundaries. Am. Mineral. 56, 909-939. 
Ross, M., Nord, G.L., JR., SMYTh, J.R. \& JAFFe, H.W. (1977): Exsolution lamellae in augite and pigeonite: fossil indicators of lattice parameters at high temperature and pressure. Am. Mineral. 62, 857-873.

SEN, S.K. (1959): Potassium content of natural plagioclases and the origin of antiperthites. J. Geol. 5, 479-495.

SMITH, J.V. (1956): The powder patterns and lattice parameters of plagioclase feldspars. I. The soda-rich plagioclases. Mineral. Mag. 31, 47-68.

(1974): Feldspar Minerals. 2. Chemical and Textural Properties. Springer Verlag, Berlin, Germany.

\& Brown, W.L. (1988): Feldspar Minerals. 1. Crystal Structures, Physical, Chemical, and Microtextural Properties (second ed.). Springer Verlag, Berlin, Germany.

\& RiBBE, P.H. (1966): X-ray emission microanalysis of rock-forming minerals. III. Alkali feldspars. J. Geol. 74, 197-216.
Willaime, C. \& Brown, W.L. (1972): Explication de l'orientation des interfaces dans les exsolutions des feldspaths, par un calcul d'énergie élastique. C. R. Acad. Sci. Paris, Sér. D 275, 627-629.

$\&$

(1974): A coherent elastic model for the determination of the orientation of exsolution boundaries: application to the feldspars. Acta Crystallogr. A30, 316-331.

Wright, T.L. \& Stewart, D.B. (1968): X-ray and optical study of alkali feldspar. I. Determination of composition and structural state from refined unit-cell parameters and 2V. Am. Mineral. 53, 38-87.

Received June 24, 1999, revised manuscript accepted April 1, 2000 
